\title{
Assessment of ion diffusion from a calcium hydroxide-propolis paste through dentin
}

\section{Janaina Corazza Montero Graziela Garrido Mori}

Endodontics Course, São Paulo Dental Association - APCD, Presidente Prudente, SP, Brazil.

Declaration of Interests: The authors certify that they have no commercial or associative interest that represents a conflict of interest in connection with the manuscript.

Corresponding Author:

Graziela Garrido Mori

E-mail:grazielagm@hotmail.com

Received for publication on Mar 16, 2012 Accepted for publication on May 12, 2012

\begin{abstract}
This study evaluated the ability of ions from a non-alcoholic calcium hydroxide-propolis paste to diffuse through dentinal tubules. Thirty-six single-rooted bovine teeth were used. The tooth crowns were removed, and the root canals were instrumented and divided into 3 groups: Group 1 - calcium hydroxide-propylene glycol paste; Group 2 - calcium hydroxide-saline solution paste; Group 3 - calcium hydroxide-propolis paste. After the root canal dressings were applied, the teeth were sealed and placed in containers with deionized water. The $\mathrm{pH}$ of the water was measured after 3, 24, 72 and 168 hours to determine the diffusion of calcium hydroxide ions through the dentinal tubules. All of the pastes studied promoted the diffusion of calcium hydroxide ions through the dentinal tubules. Associating propolis to calcium hydroxide resulted in a $\mathrm{pH}$ increase, which occurred with greater intensity after 72 hours. The calcium hydroxide-propolis paste was able to diffuse in dentin.
\end{abstract}

Descriptors: Propolis; Calcium Hydroxide; Dentin.

\section{Introduction}

One of the most important factors for successful endodontic therapy is complete root canal cleaning. ${ }^{1}$ The difficulty involved in eliminating microorganisms, as well as their residual presence, warrants the use of root canal dressings after biomechanical preparation. ${ }^{1}$

An adequate root canal dressing should have an antimicrobial potential, ${ }^{2-4}$ the ability to diffuse through dentinal tubules, ${ }^{1,3,4}$ biocompatibility, ${ }^{3,4}$ and, if possible, the ability to stimulate repair. ${ }^{3,4}$

Calcium hydroxide is one of the main root canal dressings used in Endodontics. It is a white, odorless powder, with low solubility in water, insolubility in alcohol, and a high $\mathrm{pH}$. It also has extended clinical action. Moreover, it is biocompatible, has antimicrobial and anti-inflammatory action, and activates the alkaline phosphatase enzyme, which induces mineralized tissue formation and acts in the repair process. ${ }^{4}$ It is chemically classified as a strong base, and its association with an adequate vehicle yields an alkaline paste. ${ }^{4}$

The success of calcium hydroxide paste as a root canal dressing is related to its dissociation into calcium and hydroxyl ions. The hydrox$\mathrm{yl}$ ions alkalinize the environment. ${ }^{4}$ To be effective, the hydroxyl ions should be able to diffuse in dentin and remain in pulp tissues in a sufficient concentration to produce the $\mathrm{pH}$ level required to destruct bacte- 
ria inside the root canal and dentinal tubules. ${ }^{4}$ The antimicrobial action of calcium hydroxide and its ability to contain root resorption are related to this alkalizing action, which, in turn, is a consequence of its ionization into hydroxyl ions. ${ }^{4,5}$ The action of these ions on tissues and bacteria explains the biological and antimicrobial properties of calcium hydroxide. $^{4}$

Calcium hydroxide must be associated to a vehicle to be used as a paste. ${ }^{4}$ Such vehicles include olive oil, propylene glycol, saline, distilled water, and others. ${ }^{1,4,6-8}$

Lage-Marques et al. ${ }^{8}$ conducted a study to evaluate the rate of ionic dissociation of calcium hydroxide associated to different vehicles-aqueous, viscous, and oily-and concluded that aqueous and viscous vehicles are better suited for paste use.

Propolis has been used in popular medicine for thousands of years because it is considered one of the most effective natural products discovered so far. In dentistry, propolis has been used to control the oral microbiota, e.g., in dentifrices. ${ }^{9}$

Propolis is dark in color. It is produced from material collected from plants by bees and used by them against pathogenic microorganisms. ${ }^{10}$ Its anti-inflammatory properties have been described to act mainly against infection, rheumatism, torsions, muscular and articular diseases, as well as other types of inflammation. ${ }^{10,11}$ In addition to its antibacterial and anti-inflammatory action, propolis promotes tissue reorganization. ${ }^{10}$ It is also biocompatible with pulp tissue ${ }^{11}$ and exerts antimicrobial action against endodontic pathogens. ${ }^{11-13}$

The chemical composition of propolis varies richly: Over 200 substances have been identified in the different propolis varieties from different geographical regions, including phenolic acids, flavonoids, esters, aromatic aldehydes, alcohols, amino acids, fatty acids, vitamins and minerals. ${ }^{14}$ Special emphasis should be given to the flavonoids and phenolic acids, greatly responsible for the biological activity of propolis. ${ }^{14,15}$

Owing to the antimicrobial and anti-inflammatory properties of propolis, its association with calcium hydroxide has been suggested for use as a root canal dressing. De Rezende et al. ${ }^{16}$ evaluated two propolis pastes (with and without alcohol) associated to calcium hydroxide. Even though both pastes were found to display antimicrobial action, the nonalcoholic paste produced greater inhibition halos than the paste with alcohol.

Considering the antimicrobial potential of a propolis-calcium hydroxide association, it becomes important to determine how well such a paste can promote the diffusion of ions through dentinal tubules, an attribute essential to the therapeutic effect of any calcium hydroxide paste.

The aim of this study was thus to evaluate the diffusion ability of ions from a non-alcoholic calcium hydroxide-propolis paste through dentinal tubules, compared to that of calcium hydroxide pastes prepared with saline or propylene glycol.

\section{Methodology}

This study was approved by the Institutional Review Board, Araçatuba Dental School, State University of São Paulo - UNESP (Process FOA 06021/2010).

Initially, 36 extracted single-rooted bovine teeth were kept in a $10 \%$ formaldehyde solution (FarmaTicli Indústria Farmacêutica, São Paulo, Brazil). Next, the soft tissues and dental calculus that remained adhered to the root were removed with dental scalers (Trinity, São Paulo, Brazil), after which the teeth were stored in saline solution (Farmax, Divinópolis, Brazil).

Then, the crowns were transversally sectioned with a carborundum disc (Microdont, São Paulo, Brazil), at the cementoenamel junction level.

Root canal length was measured by inserting a \#30 K-file (Maillefer Instruments, Ballaigues, Switzerland) with a rubber stop. When the file tip reached the apical foramen, the stop was leveled to the cervical edge of the root and the canal length was recorded.

The working length was established by subtracting one millimeter from the total root canal length. Apical preparation was performed up to this limit, up to file \#80, followed by a step-back instrumentation up to file \#120.

The root canals were irrigated with distilled water throughout the instrumentation procedure with 
the aid of a Luer-Lock syringe (Duflex - S.S. White Artigos Dentários Ltda., Rio de Janeiro, Brazil) and a \# $30 \times 4$ irrigation cannula $(\mathrm{BD}$ - Becton Dickinson Indústrias Cirúrgicas Ltda., Rio de Janeiro, Brazil).

After instrumentation, a \#30 file was inserted to the total working length for apical cleaning, and the root canal was filled with an EDTA solution (Biodinâmica, Ibiporã, Brazil) for 3 minutes. After this period, the root canals were rinsed with saline solution and dried with absorbent paper points (Dentsply, Petrópolis, Brazil).

The teeth were randomly divided into 3 groups according to the following calcium hydroxide pastes used to fill the canals:

- Group I (n = 12): calcium hydroxide-propylene glycol paste, prepared by mixing $1 \mathrm{~g}$ of calcium hydroxide (Biodinâmica Química e Farmacêutica LTDA, Ibiporã, PR, Brazil) and $2 \mathrm{ml}$ of propylene glycol (Odontofarma, Londrina, PR, Brazil);

- Group II ( $\mathrm{n}=12$ ): calcium hydroxide-saline paste, prepared by mixing $1 \mathrm{~g}$ of calcium hydroxide and $1.5 \mathrm{ml}$ of saline solution;

- Group III ( $\mathrm{n}=12)$ : calcium hydroxide-propolis paste, prepared by mixing $1 \mathrm{~g}$ of calcium hydroxide and $2 \mathrm{ml}$ of propolis without alcohol (Apis Flora, Ribeirão Preto, SP, Brazil).

Complete filling of the root canals was checked by having the solution overflow through the apical foramen and flow back through the root canal opening. After complete filling of the root canals, their openings were sealed with temporary cement (Cimpat-Septodont, Louisville, USA). The apical foramen and root canal openings (over the temporary cement) were sealed with epoxy resin (Araldite $^{\circledR}$ Maxepoxi Industrial e Comercial Ltda., São Paulo, Brazil). Next, the teeth were placed in containers with $50 \mathrm{ml}$ of deionized water $(\mathrm{pH}=6.17)$ and kept in an oven at $37^{\circ} \mathrm{C}$, with $100 \%$ humidity.

After 3, 24, 72 and 168 hours, the $\mathrm{pH}$ values of the solutions in the flasks were measured with a $\mathrm{pH}$ meter (Hanna Instruments Brasil Copyright, São Paulo, Brazil), calibrated with standardized solutions at $\mathrm{pH} 4.0$ and 7.0. Twelve measurements were performed for each group/period. For each measurement, the electrode of the $\mathrm{pH}$ meter was carefully rinsed with deionized water and dried with absorbent paper to eliminate any residues that could interfere with the measurements.

The data was recorded in tables and the differences between groups and periods were statistically analyzed by the Tukey test, at a significance level of $5 \%$.

\section{Results}

Figure 1 shows how the $\mathrm{pH}$ varied with time in the different study groups. The values indicate the measurement means obtained for each group.

Group 1 (propylene glycol) showed a mean $\mathrm{pH}$ of 7.992 three hours after preparing the paste and inserting it into the root canal. A significant $\mathrm{pH}$ reduction with time $(\mathrm{p}<0.05)$ was observed in this group (Table 1).

Figure $1-\mathrm{pH}$ variation over the experimental time for the study groups

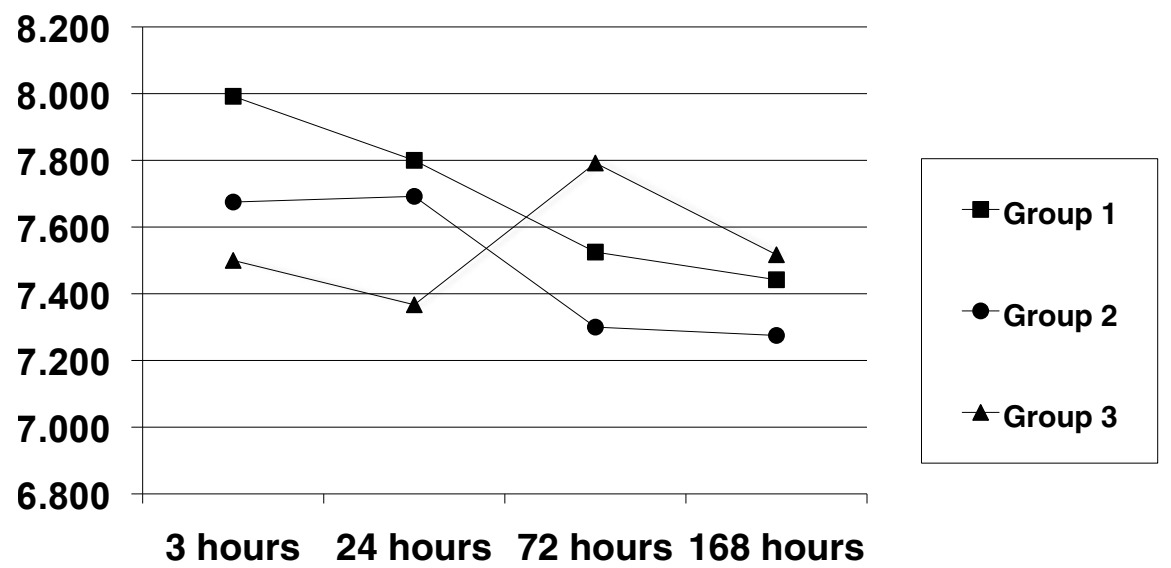


Table 1 - Mean pH obtained for the calcium hydroxide-propylene glycol paste (Group 1) after the experimental times.

\begin{tabular}{c|c|c|c|c}
\hline & 3 hours & 24 hours & 72 hours & 168 hours \\
\hline Group 1 & $7.992^{\circ}$ & $7.800^{c}$ & $7.525^{\mathrm{b}}$ & $7.442^{\mathrm{d}}$ \\
\hline
\end{tabular}

The values marked with letters " $\mathrm{a}$ " and " $\mathrm{c}$ " are significantly different from those marked with " $b$ " and " $d$ ".

Table 3 - Mean $\mathrm{pH}$ obtained for the calcium hydroxidepropolis paste (Group 3) after the different experimental times.

\begin{tabular}{l|c|c|c|c}
\hline & 3 hours & 24 hours & 72 hours & 168 hours \\
\hline Group 3 & 7.500 & $7.367^{a}$ & $7.792^{\mathrm{b}}$ & 7.517 \\
\hline
\end{tabular}

The value marked with letter " $a$ " is significantly different from that marked with " $b$ ".

Group 2 (saline) reached a mean $\mathrm{pH}$ of 7.675 and 7.692 respectively after 3 and 24 hours. There was no significant $\mathrm{pH}$ difference between these two timepoints. However, there was a significant $\mathrm{pH}$ reduction $(\mathrm{p}<0.05)$ after 72 and 168 hours, as observed in Table 2.

The $\mathrm{pH}$ in Group 3 (propolis) varied with time, with a greater $\mathrm{pH}$ increase $(\mathrm{p}<0.05)$ observed between 24 and 72 hours (Table 3).

The $\mathrm{pH}$ in group 1 was higher than that observed in the other groups $(\mathrm{p}<0.05)$ after 3 hours. Group 3 showed the lowest $\mathrm{pH}(\mathrm{p}<0.05)$ among the groups after 24 hours. Group 3 showed a pH higher than that observed in Group 2 after 72 hours $(\mathrm{p}<0.05)$. Finally, there was no $\mathrm{pH}$ difference among the groups after 168 hours, as shown in Table 4, demonstrating that all pastes were able to diffuse through the dentinal tubules and that this ability did not change over time.

\section{Discussion}

The successful use of a calcium hydroxide paste as a root canal dressing is related to its dissociation into calcium and hydroxyl ions, the latter being responsible for alkalizing the environment. ${ }^{1}$

The high $\mathrm{pH}$ of calcium hydroxide mitigates the inflammatory process, ${ }^{4}$ and its release of hydroxyl ions makes it an excellent antibacterial agent. ${ }^{4}$

Calcium hydroxide must be associated to a vehicle to be used as a paste, and this vehicle deter-
Table 2 - Mean pH obtained for the calcium hydroxidesaline paste (Group 2) after the different experimental times.

\begin{tabular}{c|c|c|c|c}
\hline & 3 hours & 24 hours & 72 hours & 168 hours \\
\hline Group 2 & $7.675^{a}$ & $7.692^{a}$ & $7.300^{\mathrm{b}}$ & $7.275^{\mathrm{b}}$ \\
\hline
\end{tabular}

The values marked with letter " $a$ " are significantly different from those marked with " $b$ ".

Table 4 - Mean $\mathrm{pH}$ obtained for the study groups after the different experimental times.

\begin{tabular}{c|c|c|c}
\hline & $\begin{array}{c}\text { Group 1 } \\
\text { (propylene glycol) }\end{array}$ & $\begin{array}{c}\text { Group 2 } \\
\text { (saline) }\end{array}$ & $\begin{array}{c}\text { Group 3 } \\
\text { (propolis) }\end{array}$ \\
\hline 3 hours & $7.992^{\mathrm{a}}$ & $7.675^{\mathrm{b}}$ & $7.500^{\mathrm{b}}$ \\
\hline 24 hours & $7.800^{\mathrm{a}}$ & $7.692^{\mathrm{a}}$ & $7.367^{\mathrm{b}}$ \\
\hline 72 hours & 7.525 & $7.300^{\mathrm{a}}$ & $7.792^{\mathrm{b}}$ \\
\hline 168 hours & 7.442 & 7.275 & 7.517 \\
\hline
\end{tabular}

The values marked with letter " $a$ " are significantly different from those marked with " $b$ ".

mines its rate of dissociation into ions and diffusion through the dentinal tubules. Additionally, the vehicle influences how well the paste can become soluble and be resorbed into the apical tissues. ${ }^{4}$ The vehicle may also bear on the effectiveness of the calcium hydroxide paste owing to its influence on ionic dissociation and diffusion. ${ }^{4}$

Lage-Marques $\mathrm{et} \mathrm{al.}{ }^{8}$ concluded that calcium hydroxide pastes in aqueous and viscous vehicles are more effective than those in oily vehicles because the former reach higher $\mathrm{pH}$ levels more quickly and remain stable for a longer period of time. Other authors have also reported the greater effectiveness of aqueous and viscous vehicles..$^{1,4,6-8}$ Similarly to previous reports, ${ }^{1,4,6-8}$ this study evidenced that saline- and propylene glycol-containing pastes diffuse well through dentin, as can be seen in Tables 1, 2 and 4. Similar levels of ion diffusion in dentin were observed for both groups, at different experimental times, confirming the indication of these substances as vehicles for calcium hydroxide pastes. The effectiveness of saline and propylene glycol as vehicles for calcium hydroxide was used as a comparative reference in this study.

According to the present results, the calcium hydroxide-propolis paste also diffused through the dentinal tubules and reached the external root sur- 
face. This may be observed in Figure 1 and Table 3. The viscous consistency of propolis probably favored this level of diffusion. Moreover, the components of the propolis solution did not impair or prevent the dissociation of the calcium hydroxide.

All of the pastes studied diffused through the dentinal tubules. After 168 hours, all of the pastes presented a similar ability to alkalize the external root surface (Table 4).

Using propolis as a vehicle for calcium hydroxide may thus be suggested. Even though the diffusion ability of the propolis-containing paste was similar to that of the saline- and propylene glycol-contain-

\section{References}

1. Mori GG, Ferreira FC, Batista FRS, Godoy AMS, Nunes DC. Evaluation of the diffusion capacity of calcium hydroxide pastes through the dentinal tubules. Braz Oral Res. 2009 Apr-Jun;23(2):113- 8.

2. Lima RK, Guerreiro-Tanomaru JM, Faria-Júnior NB, Tanomaru-Filho M. Effectiveness of calcium hydroxide-based intracanal medicaments against Enterococcus faecalis. Int Endod J. 2012 Apr;45(4):311-6.

3. Estrela C, Holland, R. Calcium hydroxide: study based on scientific evidences. J Appl Oral Sci. 2003 Dec;11(4):269- 82.

4. Mohammadi Z, Dummer PM. Properties and applications of calcium hydroxide in endodontics and dental traumatology. Int Endod J. 2011 Aug;44(8):697-730.

5. Tronstad L, Andreasen JO, Hasselgren G, Kristersin L, Riis I. $\mathrm{pH}$ changes in dental tissues after root canal fillings with calcium hydroxide. J Endod. 1981 Jan;7(1):17-21.

6. Pacios MG, de la Casa ML, de los Angeles Bulacio M, Lopes ME. Calcium hydroxide's association with different vehicles: in vitro action on some dentinal components. Oral Surg Oral Med Oral Pathol Oral Radiol Endod. 2003 Jul;96(1):96-101.

7. Zmener O, Pameijer CH, Banegas G. An in vitro study of the $\mathrm{pH}$ of three calcium dressing materials. Dent Traumatol. 2007 Feb;23(1):21-5.

8. Lage Marques JLS, Conti R, Antoniazzi JH, Guth I. Avaliação da velocidade de dissociação iônica do hidróxido de cálcio associado a diferentes veículos/ In vitro assessment of the ionic dissociation velocity of clcium hydroxide to diferente vehicles. Rev odontol Univ São Paulo. 1994 Apr-Jun;8(2):81-7. ing pastes, propolis may be a better indication because it adds to the antimicrobial action of calcium hydroxide. ${ }^{11-14}$ Further studies are warranted to investigate the biocompatibility of this paste and confirm the use of propolis without alcohol as a vehicle for calcium hydroxide.

\section{Conclusion}

The non-alcoholic calcium hydroxide-propolis paste tested in this study was able to diffuse through dentinal tubules. After 168 hours, all of the experimental pastes presented similar diffusion in dentin.

9. Ghisalbert EL. Propolis: a review. Bee Word. 1979;60(2): 59-83.

10. Marcucci MC. Propolis: chemical composition, biological properties and therapeutic activity. Apidologie. 1995;26(2):8399.

11. Bretz WA, Chiego DJ, Marcucci MC, Cunha I, Custódio A, Schneider LGZ. Preliminary report on the effects of propolis on wound healing in the dental pulp. Z Naturforsch C. 1998 Nov-Dec;53(11-12):1045-8.

12. Kayaoglu G, Ömürlü H, Akca G, Gürel M, Gençay Ö, Sorkun $\mathrm{K}$, et al. Antibacterial activity of Propolis versus conventional endodontic disinfectants against Enterococcus faecalis in infected dentinal tubules. J Endod. 2011 Mar;37(3):376-81.

13. Madhubala MM, Srinivasan N, Ahamed S. Comparative evaluation of propolis and triantibiotic mixture as an intracanal medicament against Enterococcus faecalis. J Endod. 2011 Sep;37(9):1287-9.

14. Gonsales GZ, Orsi RO, Fernandes Júnior A, Rodrigues P, Funari, S. Antibacterial activity of propolis collected in different regions of Brazil. J Venom Anim Toxins Incl Trop Dis. 2006 Apr-Jun;12(2):276-84.

15. Mori GG, Nunes DC, Castilho LR, de Moraes IG, Poi WR. Propolis as storage media for avulsed teeth: microscopic and morphometric analysis in rats. Dent Traumatol. 2010 Feb;26(1):80-5.

16. de Rezende GP, da Costa LR, Pimenta FC, Baroni DA. In vitro antimicrobial activity of endodontic pastes with propolis extracts and calcium hydroxide: a preliminary study. Braz Dent J. 2008;19(4):301-5. 